https://doi.org/10.19195/0524-4544.333.31

\author{
DANIEL WACINKIEWICZ \\ ORCID: 0000-0002-5048-9866 \\ Uniwersytet Szczeciński \\ daniel.wacinkiewicz@usz.edu.pl
}

\title{
Horyzontalny wymiar zasady subsydiarności - uwagi w kontekście koncepcji decentralizacji i samorządu terytorialnego Tadeusza Bigi
}

\begin{abstract}
Abstrakt: Spojrzenie przez pryzmat wyników badań prof. Tadeusza Bigi na temat związków publicznoprawnych na problematykę zasady pomocniczości doskonale obrazuje sprzężenie, w jakim pozostają zasady decentralizacji i subsydiarności. Zasady te znakomicie się uzupełniają, wskazując na określony sposób sprawowania władzy — opartej na zrozumieniu publicznej roli, jaką mogą i powinni odgrywać w życiu publicznym obywatele i tworzone przez nich instytucje; władzy zdolnej do dzielenia się zadaniami publicznymi z podmiotami prywatnymi (obywatelami, ich grupami, wspólnotami, tworzonymi przez nich organizacjami) i wspierającej ich inicjatywy.

Współcześnie obok wymiaru wertykalnego coraz istotniejszą rolę odgrywa również horyzontalny wymiar zasady subsydiarności. Jego istotą jest zapewnienie takiego sposobu wykonywania zadań publicznych, by w jak największym stopniu były one realizowane przez instytucje społeczeństwa obywatelskiego. Organy administracji publicznej, w tym jednostki samorządu terytorialnego, stanowią w takim modelu struktury pośredniczące pomiędzy obywatelami a państwem. Wymaga to stworzenia swoistego ,podziału pracy” między sektorem publicznym a obywatelskim.
\end{abstract}

Słowa kluczowe: subsydiarność, subsydiarność horyzontalna, decentralizacja, samorząd terytorialny.

Jeśli doskonała demokracja oznacza zespolenie (identyfikację) jednostki ze zbiorowością, to samorząd może być pośrednim etapem tego procesu, jego ogniwem [...].

Tadeusz Bigo, Związi publiczno-prawne w świetle ustawodawstwa polskiego, Warszawa 1928, s. 218. 


\section{Wprowadzenie}

Ponadczasowość jest cechą przynależną jedynie wybitnym dziełom naukowym. Upływ czasu, zmiany kulturowe, polityczne, społeczne, gospodarcze czy technologiczne nie naruszają istoty fundamentalnych ustaleń - czyniąc z nich punkt odniesienia dla kolejnych generacji badaczy. Niewątpliwie, z takim dziełem mamy do czynienia w przypadku monografii Zwiąki publiczno-prawne w świetle ustawodawstwa polskiego Tadeusza Bigi ${ }^{1}$. W szczególności Jego sposób myślenia o decentralizacji, samorządzie i demokracji, pomimo upływu przeszło 90 lat od chwili powstania dzieła, nie tylko zachowuje zdumiewającą aktualność, ale także jest równie inspirujący, jak miało to miejsce w okresie międzywojnia.

Publikacja ustaleń naukowych Profesora Tadeusza Bigi z końca lat dwudziestych poprzedniego wieku niemal zbiegła się z wydarzeniem o szczególnej doniosłości dla kultury europejskiej, jakim było ostateczne sformułowanie idei subsydiarności w społecznej nauce Kościoła katolickiego. Dokonało się to na kartach encykliki Quadragesimo Anno ${ }^{2}$ papieża Piusa XI. Wpływ tego wydarzenia na formowanie się ówczesnego kształtu samorządu terytorialnego nie był ani oczywisty ani jaskrawo dostrzegany.

Musiały upłynąć dziesięciolecia i zaistnieć wielkie i dramatyczne wydarzenia historyczne zmieniające kierunki rozwoju naszego kontynentu, by w oparciu o tę wyrastającą z założeń personalistycznej koncepcji człowieka ideę zaczęto konstruować porządki ustrojowe i prawne. Tym samym idea subsydiarności uzyskała swój prawny wyraz. Stała się — wraz z wartościami takimi jak demokracja, poszanowanie praw jednostki, współdziałanie władz, dialog społeczny — jednym z fundamentów ustrojowych współczesnych państw europejskich ${ }^{3}$, a także tworzonych przez nie struktur (w tym Rady Europy i Unii Europejskiej) ${ }^{4}$.

1 T. Bigo, Związi publiczno-prawne w świetle ustawodawstwa polskiego, Warszawa 1928.

2 Pius XI, Quadragesimo Anno z 15 maja 1931 roku, przeł., wstęp i komentarz J. Piwowarczyk, Kielce 1946.

3 Zasada subsydiarności jest obecna w konstytucjach państw europejskich. Za przykład posłużyć może Konstytucja Republiki Włoskiej, w której art. 118 zawarto regulację: „Le funzioni amministrative sono attribuite ai Comuni salvo che, per assicurare 'esercizio unitario, siano conferite a Province, Citta metropolitane, Regioni e Stato, sulla base dei principi di sussidiarieta, differenziazione ed adeguatezza". W oparciu o tę regulację, gminy stanowią podstawowy poziom włoskiego samorządu terytorialnego o kompetencji ogólnej; szerzej na ten temat zob. M. Kruczkowski, Zasada pomocniczości w prawie publicznym Wtoch, „Zeszyty Prawnicze Biura Analiz Sejmowych” 2014, nr 1, s. 58-59.

4 Zasada subsydiarności znajduje odzwierciedlenie w aktach normatywnych przyjmowanych pod auspicjami organizacji takich jak Rada Europy czy Unia Europejska. Pomimo wielości sposobów rozumienia zasady subsydiarności i jej wpływu na „europejski projekt”, dostrzegalna jest zbieżność stanowisk co do celu, jakiemu ma ona służyć w kontekście działalności regionalnych organizacji międzynarodowych. Są nimi, jak zauważa M. Cahill, zapobieganie centralizacji (,subsidiarity as a mechanism to prevent centralization at the European level") i ochrona pozycji państw członkowskich (,to protect the position of the member states”); zob. idem, Theorizing subsidiarity: Towards an ontology-sensitive approach, „International Journal of Constitutional Law” 15, 2017, nr 1, s. 203.

Prawo 333, 2021

(C) for this edition by CNS 
Zasada subsydiarności stała się również jedną z naczelnych zasad ustroju Rzeczpospolitej Polskiej, wyrażoną explicite w preambule Konstytucji RP w zwrocie: ,prawa podstawowe dla państwa oparte [...] na zasadzie pomocniczości umacniającej uprawnienia obywateli i ich wspólnot”. Adresatami tej regulacji są niewątpliwe wszystkie władze publiczne, bo to ich powinnością jest umacnianie (między innymi w swojej działalności) „uprawnień obywateli i ich wspólnot”.

Wskazane okoliczności i uwarunkowania skłaniają do przemyślenia, w jaki sposób zasada subsydiarności łączy się z ustaleniami prof. Tadeusza Bigi dotyczącymi decentralizacji i samorządu terytorialnego. W szczególności, interesujące jest, jakie znaczenie w tym kontekście należy przypisać tak zwanemu horyzontalnemu aspektowi zasady subsydiarności. Zagadnienie to uczyniono podstawowym celem badawczym niniejszego opracowania.

\section{Wybrane elementy koncepcji decentralizacji Tadeusza Bigi}

W koncepcji związków publicznoprawnych Tadeusza Bigi istotną rolę odgrywały ustalenia odnoszące się do decentralizacji administracji. Przedmiot zainteresowania stanowiła decentralizacja prawno-administracyjna, oznaczająca „taki system — w którym istnieje większa ilość ośrodków administracji publicznej”6.

${ }^{5}$ Choć treść zasady subsydiarności nie została rozwinięta w przepisach Konstytucji RP, to nie ulega wątpliwości, że można ją rekonstruować także na gruncie innych jej postanowień (szczególności odnoszących się do samorządu terytorialnego). Wynika z nich między innymi, że samorząd terytorialny uczestniczy w sprawowaniu władzy publicznej, a przysługującą mu w ramach ustaw istotną część zadań publicznych samorząd wykonuje w imieniu własnym i na własną odpowiedzialność (art. 16 ust. 2). Co szczególnie istotne, to właśnie ten samorząd wykonuje zadania publiczne, które nie zostały zastrzeżone przez prawo (Konstytucję, ustawy) dla organów innych władz publicznych (art. 163). Wśród tych zadań najistotniejszą rolę odgrywają zadania publiczne służące zaspokajaniu potrzeb wspólnoty samorządowej. Konstytucja rozstrzyga, że są one wykonywane przez jednostkę samorządu terytorialnego jako zadania własne (art. 166 ust. 1). Konstytucja wskazuje również, że podstawową jednostką samorządu terytorialnego jest gmina (art. 164 ust. 1), która — co szczególnie istotne z punktu widzenia zasady subsydiarności — stanowi pierwszy, znajdujący się „najbliżej mieszkańców” poziom struktury samorządowej. W doktrynie oraz orzecznictwie, jak trafnie zauważa Jerzy Korczak, stało się podstawą do szeroko interpretowanych wniosków dotyczących między innymi miejsca samorządu terytorialnego w państwie i wzajemnych relacji między organami władzy publicznej. Dekodowanie tego wzorca wciąż stwarza wiele możliwości interpretacyjnych, zaś orzecznictwo przypisuje subsydiarności znaczenie fundamentalne. Zob. J. Korczak, Konstytucyjne podstawy struktury i funkcji samorzqdu terytorialnego [w:] System Prawa Administracyjnego, t. 2. Konstytucyjne podstawy funkcjonowania administracji publicznej, red. R. Hauser, Z. Niewiadomski, A. Wróbel, Warszawa 2012, s. 177. Korczak zwraca uwagę, że zasada subsydiarności jest szczególnie przydatna dla konstruowania klauzul kompetencyjnych w ramach ustroju samorządowego wieloszczeblowego (gdy między jednostkami samorządu zachodzą relacje organizacyjno-ustrojowe), jak i wielopodmiotowego (jak w Polsce, gdy pomiędzy samorządami poziomu gminnego, powiatowego i wojewódzkiego nie zachodzą żadne zależności). Zob. ibidem, s. 181.

${ }^{6}$ Ibidem, s. 121.

Prawo 333, 2021

(C) for this edition by CNS 
W tym znaczeniu, jak zauważał, „decentralizacja jest to system administracji, przy którym podmioty administrujące mają samodzielność w stosunku do centralnej władzy. Negatywnie opisujemy rzecz, że decentralizacja polega na uchyleniu hierarchicznego podporządkowania"7. Stanowisko swoje doprecyzowywał poprzez uwypuklenie jeszcze dwóch istotnych elementów, stwierdzając: „w powyższem opisaniu opiera się ona [to jest decentralizacja — D.W.] na momentach strukturalnych [...]: kto (podmiot) i jak (w sposób samodzielny) administruje" 8 . Dla Tadeusza Bigi „moment treści” był natomiast całkowicie nieistotny — to nie on decydował, co jest przedmiotem zdecentralizowanej administracji. Artykułowat to dobitnie:

decentralizacja nie ma nic wspólnego z wyobrażeniami treści działalności administracyjnej [...]. Nie treść działalności jest kryterium rozróżnienia systemów: decentralistycznego i centralistycznego. Nie można przeprowadzić rozgraniczenia według kryterium materialnego; nie ma spraw, które z natury swej należą do administracji zdecentralizowanej ${ }^{9}$.

Konstatacje te stanowiły punkt wyjścia do ustaleń dotyczących zakresów nazw „decentralizacja” i ,samorząd”. Tadeusz Bigo za błędne uważał stanowisko identyfikujące decentralizację z samorządem i uznające obie nazwy za synonimy — stwierdzając: ,samorząd jest m. zd. jednym typem decentralizacji, decentralizacja jest pojęciem szerszem, nadrzędnem" 10 .

Na tym tle, konsekwentnie, odrzucał teorie samorządu opierające się na jego „momentach materjalnych”, to znaczy „teorie określające samorząd jako zarząd spraw o specyficznym charakterze" ${ }^{11}$. Konstatowat:

moment materjalny występuje w innej postaci w teorjach, według których kwalifikuje się sprawy należące do samorządu jako sprawy lokalne. Otóż, rozgraniczenie na sprawy ogólne (państwowe) i lokalne jest a prori niemożliwe; nie możemy nigdy powiedzieć, które sprawy „z natury rzeczy” mają charakter lokalny. Możemy to uczynić tylko w oparciu — o prawo pozytywne ${ }^{12}$.

Zaprezentowane ustalenia, a także refleksje poświęcone klasycznym z dzisiejszej perspektywy - teoriom samorządu terytorialnego, w tym zwłaszcza polemiki z innymi wielkimi twórcami myśli samorządowej ${ }^{13}$ doprowadziły Tadeusza Bigę do sformułowania kluczowych tez:

a) — samorząd jest jednym typem decentralizacji administracji; b) — przedmiot samorządowej administracji nie różni się od przedmiotu administracji rządowej; $\mathrm{z}$ tego punktu widzenia nie można

${ }^{7}$ Ibidem, s. 123.

8 Ibidem.

${ }^{9}$ Ibidem. Stanowisko to było konsekwentnie prezentowane przez T. Bigę w kolejnych latach. Zob. m.in. T. Bigo, Prawo administracyjne, cz. 1. Instytucje ogólne, oprac. W. Kawka, Wrocław 1948, zob. zwł. s. 84-86.

10 T. Bigo, Zwiazki..., s. 124.

11 Ibidem, s. 125.

12 Ibidem, s. 126.

13 W tym zwłaszcza z Jerzym Panejką i jego tezach zawartych w monografii Geneza i podstawy samorządu europejskiego (1926). 
przeciwstawić administracji samorządowej — administracji państwowej, bo samorząd jest tylko odmienną formą organizacyjną administracji państwowej; c) - takie przeciwstawienie jest natomiast dopuszczalne z punktu widzenia podmiotów administracji, bo podmiotem administracji samorządowej jest nie państwo, ale odrębne podmioty, odrębne osoby prawne ${ }^{14}$. Dlatego nie uważam, jakoby przeciwstawienie: administracja państwowa i samorządowa — było bezsensem z tego punktu widzenia [...] d) — jednostki samorządowe jako osoby prawne wyróżniają się tem, że posiadają obowiązki i prawa (publiczne), zapewniające im stanowisko równorzędne z władzami rządowemi tj. władztwo ${ }^{15}$ administracyjne ${ }^{16}$.

\section{Źródła i istota zasady subsydiarności}

Równolegle do prezentacji poglądów Bigi na temat związków publicznoprawnych wyraźnie wyeksplikowana została jedna z najistotniejszych idei dla współczesnych państw demokratycznych — idea subsydiarności.

Sformułowana w latach trzydziestych XX wieku w opozycji do socjalizmu (w jego dwóch głównych nurtach — komunizmu i socjaldemokratyzmu), a także liberalizmu, idea subsydiarności stanowiła próbę odnowienia ustroju społecznego. Odegrała i wciąż odgrywa ważną rolę w kształtowaniu myśli społeczno-polityczno-prawnej, przynosząc odpowiedzi na fundamentalne pytania: po co jest władza? Jakim celom powinna ona służyć i jaką rolę ma odgrywać? ${ }^{17}$ Jaki jest zakres samodzielności i samowystarczalności obywatela, grup społecznych, mniejszych i większych społeczności w różnych sferach funkcjonowania państwa? ${ }^{18}$

Źródeł idei subsydiarności - myśli i refleksji filozoficznej, która ukształtowała współczesne rozumienie tej zasady ${ }^{19}$ — poszukiwać możemy na różnych etapach rozwoju kultury europejskiej. Pojawia się ona już w filozofii antycznej u Arystotelesa $^{20}$ jako ważne rozwinięcie jego filozofii polityki, stanowiąc impli-

14 Tę cechę T. Bigo wyraźnie podkreślał i eksplikował w dalszej części wywodu: „Tem co indywidualizuje samorząd i wyodrębnia spośród administracji jest — osobowość prawna jednostek samorządowych" - idem, Związki..., s. 141.

15 „Związki publ.-prawne posiadają władztwo administracyjne, a zatem — są one (albo raczej ich działalność) częścią administracji publicznej. Samorząd zaś jest zdecentralizowaną administracją, wykonywaną przez samodzielne związki. Zatem związki publ.-prawne są związkami samorządowemi. Związki publiczno-prawne i związki samorządowe - to dwa synonimy: zakresy tych nazw pokrywają się. Samorząd jest oznaczeniem formy administracji, wyraża stosunek osób administrujących do państwa, określa tylko jedną relację podmiotu administracji. Związek publ.-prawny jest oznaczeniem samego podmiotu administracji” — ibidem, s. 154.

16 Ibidem, s. $140-141$.

17 Ch. Millon-Delsol, Zasada pomocniczości, Kraków 1995, s. 6-7.

18 B. Dolnicki, Samorzad terytorialny, Warszawa 2012, s. 23.

19 Szerzej na ten temat zob. D. Wacinkiewicz, Zaspokajanie potrzeb wspólnot samorzadowych. Studium administracyjnoprawne, Warszawa 2016, s. 289-294.

20 To zapewne Platońska myśl, że ,państwo tworzy się dlatego, że żaden z nas nie jest samowystarczalny, tylko mu potrzeba wielu innych. Albo jaki, myślisz, może być inny początek i zasada 
kację krytyki komunizmu Platona ${ }^{21}$. Jest obecna w średniowiecznej nauce św. Tomasza z Akwinu, a także w oświeceniowych koncepcjach Johna Locke'a i Jeana-Jacques'a Rousseau. Jednak niewątpliwym momentem przełomowym jest było wyrażenie jej założeń w społecznej nauce Kościoła katolickiego.

Mimo że po raz pierwszy idea subsydiarności znalazła wyraz w encyklice Rerum Novarum z 1891 roku $^{22}$, to wyraźne jej nazwanie, a także sformułowanie reguł subsydiarności, dokonało się 40 lat później, w encyklice Piusa XI Quadragesimo Anno z 1931 roku. Jej istotę najpełniej wyraża myśl, że to, co jednostka, małe społeczności czy wspólnoty mogą uczynić z własnej inicjatywy i własnymi siłami, nie wolno im zabierać na rzecz społeczeństwa. Odbieranie im zadań, które są w stanie realizować jest traktowane na gruncie Quadragesimo Anno jako „niesprawiedliwość i szkoda społeczna"23. Każda interwencja w życie społeczne ze względu na swój cel i na swoją naturę winna mieć charakter pomocniczy — pomagając organizmowi społecznemu, a nie pochłaniając go $^{24}$.

zakładania państw?” (zob. Platon, Państwo, ks. II, 369 B, przeł. W. Witwicki, Kęty 2003), znajduje się u źródeł inspiracji Arystotelesa, które rozwinięte zostały w jego Polityce.

21 J. Finnis, Prawo naturalne i uprawnienia naturalne, przeł. K. Lossman, Warszawa 2001, s. 177.

22 Leon XIII, Rerum Novarum z 15 maja 1891 roku, przeł., wstęp i objaśnienia J. Piwowarczyk, Kraków 1931. Za słuszną i uzasadnioną opiekę uznano w niej konieczność udzielenia przez państwo pomocy rodzinie znajdującej się w trudnej sytuacji (,,jeśli się jakaś rodzina znajdzie w wielkich trudnościach i bez rady, że sama się z nich wyzwolić nie może, jest rzeczą słuszną, by jej w tych ostatecznościach państwo udzieliło pomocy [...] będzie to niepochłanianiem praw obywatelskich, ale ich obroną i wykonywaniem słusznej, a powinnej opieki” - ibidem, s. 33 oraz ,prawo wymaga, żeby ani jednostka, ani rodzina nie była pochłaniana przez państwo; jest więc rzeczą słuszną, by i jednostka i rodzina miała swobodę działania" - ibidem, s. 61). Nie ulega żadnej wątpliwości, że Leon XIII ma świadomość zagrożeń jakie niesie za sobą interwencjonizm państwowy. Jak komentuje ten fragment Encykliki ks. J. Piwowarczyk, „zastosowany bez ograniczeń łatwo może doprowadzić do zupełnego pochłonięcia społeczeństwa (praw jednostek, rodzin, innych naturalnych zrzeszeń) przez państwo, do zniweczenia inicjatywy i własności prywatnej”- - ibidem, s. 62).

23 Pius XI wyraża to w następujących słowach: „niewzruszalnym i niezmiennym pozostaje to ważne prawo filozofii społecznej: jak nie wolno jednostkom wydzierać i na społeczeństwo przenosić tego, co mogą wykonać z własnej inicjatywy i własnymi siłami, podobnie niesprawiedliwością, szkoda społeczną i zakłóceniem porządku jest zabieranie mniejszym i niższym społecznościom tych zadań, które mogą spełnić, i przekazywanie ich społecznościom większym i wyższym” — Quadragesimo Anno, s. 58.

${ }^{24}$ Do kwestii proporcjonalności działania ze strony państwa nawiązywał także Jan Paweł II w encyklice Centesimus Annus, wydanej w stulecie ukazania się Rerum Novarum, stwierdzając: „Niesprawności i niedostatki w Państwie opiekuńczym wynikają z nieodpowiedniego rozumienia właściwych Państwu zadań. Także w tej dziedzinie winna być przestrzegana zasada pomocniczości, która głosi, że społeczność wyższego rzędu nie powinna ingerować w wewnętrzne sprawy społeczności niższego rzędu, pozbawiając ją kompetencji, lecz raczej winna wspierać ją w razie konieczności i pomóc w koordynacji jej działań z działaniami innych grup społecznych, dla dobra wspólnego". Konsekwencje błędnego pojmowania roli (zadań) państwa są aż nadto oczywiste, a zarazem negatywne. Zob. Jan Paweł II, Encyklika Centesimus annus, [w:] Encykliki Ojca Świętego Jana Pawta II, t. 2, Kraków 1996, s. 517-518.

Prawo 333, 2021

(C) for this edition by CNS 
Dla wyrastającej z założeń personalistycznej koncepcji człowieka zasady subsydiarności kluczową, centralną wartość stanowi przyrodzona godność każdej osoby ludzkiej ${ }^{25}$. Niezależnie od jej źródeł, przejawów i natury, godność człowieka jest etycznym i prawnym wyrazem potrzeby autonomii, szacunku, poważania jak i samorealizacji, z kolei potrzeba godnego traktowania tkwi w każdej osobie ludzkiej ${ }^{26}$. To właśnie z poszanowania ludzkiej godności wynika - kluczowe dla realizacji zasady subsydiarności — ustalenie, iż ludzie wolni i odpowiadający za swoje działania są zarazem, w pierwszej kolejności, sami odpowiedzialni za zaspokajanie swoich własnych potrzeb. Mogą do tego celu wykorzystać wszelkie posiadane uprawnienia, zasoby i możliwości — a ich dobór jest kwestią wyboru (wolnej woli) jednostki.

Niemożności zaspokajania niezbędnych potrzeb we własnym zakresie, otwiera przestrzeń do wsparcia osoby potrzebującej „z zewnątrz” — to znaczy ze strony społeczności, wspólnot i instytucji społeczeństwa obywatelskiego. Kolejność interwencji wyznacza swoista bliskość podmiotu wspierającego względem osoby potrzebującej. I tak, w pierwszej kolejności pomoc pochodzi od najbliższej wspólnoty, jaką stanowi rodzina. Następnie, uwzględniając fakt, że żyjemy w społeczeństwie zorganizowanym (składającym się z wielu poziomów zorganizowania), otwiera się przestrzeń dla interwencji instytucji społeczeństwa obywatelskiego (w szczególności organizacji pozarządowych).

Dopiero niemożność zaspokojenia swoich potrzeb związana z nieprzezwyciężalnymi trudnościami, w ramach działania tak indywidualnego (samodzielnego), jak i zbiorowego (wspólnotowego, kolektywnego), stwarza podstawę do działania ze strony władzy publicznej. To wówczas bowiem pojawia się zadanie publiczne $^{27}$. Jego istotą i treścią jest pomoc osobom potrzebującym w pokonywaniu problemów życiowych, nieprzezwyciężalnych za pomocą własnych uprawnień, zasobów i możliwości, a także usuwanie przyczyn takiego stanu i przywrócenie osoby do normalnego funkcjonowania społecznego - służą umożliwieniu życia w warunkach odpowiadających godności człowieka.

Tak rozumiane uzasadnienie interwencji ze strony władzy publicznej wymaga jeszcze jednego wyraźnego uzupełnienia: władze publiczne działać mają wyłącznie w celu i w granicach koniecznej pomocy. Jedynie wówczas mają one obowiązek przychodzić z pomocą osobom potrzebującym. Nie ma tu mowy o dowolności, swobodzie zakresu działań ze strony władz publicznych, a już tym bardziej o przyzwoleniu na nadmiernie szeroki zakres interwencji.

Zaprezentowany sposób pojmowania zasady subsydiarności pozwala na: po pierwsze, określenie istoty zadań publicznych (rozwiązywanie problemów jednostkowych i zbiorowych, nierozwiązywalnych w ramach społeczeństwa obywa-

${ }^{25}$ H. Izdebski, Doktryny polityczno-prawne. Fundamenty wspótczesnych państw, Warszawa 2015, s. 171.

26 D. Wacinkiewicz, op. cit., s. 494.

27 H. Izdebski, Samorząd terytorialny. Podstawy ustroju i działalności, Warszawa 2011, s. 147. 
telskiego); po drugie - dokonanie podziału zadań publicznych pomiędzy różne poziomy władz publicznych (to znaczy pionowy podział zadań publicznych pomiędzy poszczególne władze).

Oba wymienione aspekty tradycyjnie zalicza się do kategorii tak zwanej subsydiarności wertykalnej (pionowej). Obok nich dostrzega się istnienie trzeciego aspektu zasady subsydiarności - a mianowicie subsydiarności horyzontalnej (poziomej).

\section{Subsydiarność horyzontalna}

Współcześnie to nie klasyczne, wertykalne aspekty zasady subsydiarności skupiają największą uwagę badaczy nauk społecznych i humanistycznych (w tym prawników, socjologów, politologów czy filozofów), lecz jej horyzontalny wymiar ${ }^{28}$.

Jak stwierdza Hubert Izdebski, ten aspekt zasady subsydiarności stanowi ,implikację zasady społeczeństwa obywatelskiego w powiązaniu z zasadą dialogu społecznego" i polega na zapewnieniu takiego sposobu wykonywania zadań publicznych, by w jak największym stopniu były one realizowane przez instytucje społeczeństwa obywatelskiego. Dzięki temu ma być zapewnione dobro wspólne ${ }^{29}$.

W literaturze obcojęzycznej subsydiarność horyzontalna bywa różnie charakteryzowana. Niekiedy akcentuje się, że jej treścią jest delegowanie tworzenia polityk publicznych do podmiotów niepaństwowych (niepublicznych) - do których zalicza się przedsiębiorców, organizacje pozarządowe i innych uczestników społeczeństwa obywatelskiego ${ }^{30}$. W innych ujęciach zauważa się także, że horyzontalny wymiar zasady subsydiarności umożliwia postrzeganie społeczeństwa jako konglomeratu różnych dziedzin: rynku, państwa i społeczeństwa obywatelskiego wraz ze swoją specyfiką i unikalnymi mechanizmami koordynacji ${ }^{31}$. Inni autorzy, eksponują z kolei, że zróżnicowany charakter ustaleń społecznych wynikający ze współpracy różnych interesariuszy ${ }^{32}$, nadto dostrzegając, że elementy takie jak aktywna partycypacja, zaangażowanie, sieciowanie współpracy podmiotów z różnych obszarów (administracji, biznesu, społeczeństwa obywatelskiego) są $\mathrm{w}$ tym procesie niejako celami samym w sobie.

Nierzadko znaczące różnice poglądów na jej temat, a także różnorodne akcentowanie elementów istotnych pojęcia i konstrukcji horyzontalnego aspektu

28 Zob. też D. Wacinkiewicz, Horizontal dimension of subsidiarity in the activity of Polish local government, Granada 2020, s. 11224-11229.

${ }^{29}$ H. Izdebski, Doktryny polityczno-prawne. Fundamenty współczesnych państw, Warszawa 2015, s. 172-173.

30 A. Colombo, The Principle of Subsidiarity and European Citizenship, Milan 2004, s. 39.

31 W. van de Donk, Subsidiarity as an experience and inspiration: The case for Regionomics in North Brabant, „European View” 18, 2019, nr 1, s. 47.

32 R. Mulé, G. Walzenbach, Introduction: two spaces of subsidiarity?, „Commonwealth \& Comparative Politics" 57, 2019, nr 2, s. 141. 
zasady subsydiarności nie są niczym zaskakującym. Skądinąd, podobny wielogłos towarzyszy sposobom pojmowania, opisywania i definiowania również subsydiarności wertykalnej. Jest to o tyle zrozumiałe, że jak powyżej wskazywałem, problematyka ta stanowi przedmiot badań różnych dyscyplin naukowych. Uznać zatem należy, że również na grunt analiz prawniczych trafia z całym swoim bogactwem znaczeń ustalonym już przez fizjologów, socjologów czy politologów. Co więcej, stanowi takiemu sprzyja okoliczność, że normatywne odzwierciedlenie zasady subsydiarności horyzontalnej w porządkach prawnych poszczególnych państw (organizacji międzynarodowych) jest stosunkowo skromne ${ }^{33}$, przyjmowane zaś rozwiązania - zróżnicowane ${ }^{34}$.

Na gruncie powyższego i mając na względzie zasadniczy cel badawczy niniejszego opracowania, uwagę musimy skupić na, zdawać by się mogło, dość oczywistej kwestii - w jakim związku pozostają ze sobą decentralizacja i subsydiarność.

Przypomnijmy, że Tadeusz Bigo charakteryzował decentralizację jako system, w którym istnieje większa ilość ośrodków administracji publicznej mających samodzielność w stosunku do władzy centralnej. Z kolei subsydiarność, zgodnie z przyjętym wcześniej znaczeniem, wymaga wielopoziomowego (wieloszczeblowego) i opartego właśnie na zasadzie decentralizacji podziału władzy w organizacji państwowej. W oparciu o niego realizowany jest podział zadań i kompetencji wyrażający ideę: zadania zaspokajające potrzeby obywateli (wspólnot samorządowych) powinny być wykonywane przez organy znajdujące się najbliżej nich. Realizacja zadań przez wyższe poziomy struktur administracyjnych jest uzasadniona, gdy przekracza to możliwości struktur niższego stopnia, a tym samym jest to bardziej efektywne. Organy wyższych poziomów albo szczebli struktur administracyjnych powinny wspomagać i uzupełniać działalność organów niższych dopiero wówczas, gdy te nie są samowystarczalne.

33 Wyrażenie zasady subsydiarności horyzontalnej w regulacji prawnej rangi konstytucyjnej jest sytuacją wyjątkową. Najbardziej jaskrawą egzemplifikację stanowi art. 118 Konstytucji Republiki Włoskiej. Zgodnie z nim: państwo, regiony, miasta metropolitalne, prowincje i gminy sprzyjają niezależnej inicjatywie obywateli, (zarówno działających indywidualnie, jak i stowarzyszonych), która to inicjatywa służy działaniom na rzecz interesu powszechnego, zgodnie z zasadą subsydiarności (art. 118 La Costituzione: 'Stato, Regioni, Città metropolitane, Province e Comuni favoriscono l'autonoma iniziativa dei cittadini, singoli e associati, per lo svolgimento di attività di interesse generale, sulla base del principio di sussidiarietà". Źródło: https://www.senato.it/1025?sezione=136\&articolo_ numero_articolo=118 (dostęp: 22.04.2021). W literaturze zwraca się uwagę, że zasada pomocniczości doznaje w tym przepisie ograniczenia przez klauzulę interesu powszechnego (interesse generale). Pomocniczość we włoskim przypadku — odmiennie niż w polskich rozwiązaniach — dotyczy więc tylko tej aktywności obywateli, która służy interesowi powszechnemu. Zob. na ten temat M. Kruczkowski, op. cit., s. 58. Niewątpliwie jednak z regulacji tej wywodzić można dyrektywę powierzania wykonywania zadań publicznych instytucjom społeczeństwa obywatelskiego.

${ }^{34}$ Porządki prawne poszczególnych państw europejskich, jak i prawne ramy funkcjonowania organizacji międzynarodowych (prawo pierwotne i prawo wtórne) mogą regulować zasadę subsydiarności na różne sposoby — czyniąc z niej zarówno „twardą dyrektywę”, jak i „miękką rekomendację”. 
Powstały w ten sposób system dystrybucji zadań w ramach administracji publicznej (rządowej i samorządowej) oparty jest o założenie realizacji jak najszerszego zakresu zadań publicznych na poziomie władzy najbliższemu obywatelowi. Podkreślenia zarazem wymaga, że ta sama reguła znajduje zastosowanie do poza-administracyjnych form organizacji społeczeństwa - rodzina pomaga jednostce, rodzinie pomaga wspólnota i organizacje sektora obywatelskiego itp. Skłania to ku konstatacji, bardzo trafnie wyrażonej przez Irenę Lipowicz, że zasada pomocniczości i zasada decentralizacji znakomicie się uzupełniają - chodzi bowiem o sposób postrzegania sprawowania władzy jako wyrastającej ze wspólnoty podstawowej z dołu do góry ${ }^{35}$. Patrząc z tej perspektywy — organy administracji publicznej, w tym jednostki samorządu terytorialnego, stanowią struktury pośredniczące pomiędzy obywatelami a państwem.

Nałóżmy na powyższe zaproponowany wcześniej sposób pojmowania subsydiarności horyzontalnej - jako wyrażającej dyrektywę jak największego stopnia realizacji zadań publicznych przez instytucje społeczeństwa obywatelskiego. Chcąc zwiększać rolę tych ostatnich, a zarazem podkreślać znaczenie partycypacji obywateli w życiu społecznym, powinniśmy postrzegać zasadę subsydiarności nie tylko jako na regułę ustawowo uregulowanego rozproszenia władzy pomiędzy instytucje publiczne, ale również jako zasadę uznającą publiczną rolę aktorów niepublicznych — obywateli i organizacji pozarządowych. W tym kontekście to właśnie aspekt horyzontalny był $\mathrm{w}$ istocie pierwotnym znaczeniem zasady subsydiarności ${ }^{36}$.

$\mathrm{W}$ analizach poświęconych interesującemu nas zagadnieniu pewien element wart jest wyraźnego podkreślenia: subsydiarność pozioma jest ukierunkowana na realizację interesu publicznego ${ }^{37}$. Jest to cecha wyróżniająca (nabierająca istotnego znaczenia wówczas, gdy przypomnimy, że nie wszystkie działania organizacji sektora obywatelskiego muszą ją posiadać ${ }^{38}$. W przypadku zasady subsydiarności horyzontalnej chodzi jednak o realizację zadań publicznych. Obywatele inicjują w ten sposób działania służące realizacji dobra wspólnego. Tu dochodzimy do niezwykle istotnej kwestii — wyrażającej złożoność i trudność realizacji zasady subsydiarności poziomej. Otóż przekazywanie zadań publicznych do wykonywania instytucjom społeczeństwa obywatelskiego wymaga stworzenia swoistego „podział pracy” pomiędzy sektorem publicznym i obywatelskim ${ }^{39}$. Pomocniczość horyzontalna odnosi się przecież do dzielenia się kompetencjami i inicjatywami pomiędzy podmiotami publicznymi i prywatnymi (obywatelami, instytucjami

35 I. Lipowicz, Samorząd terytorialny XXI wieku, Warszawa 2019, s. 137-138.

${ }^{36}$ Zob. A. Colombo, op. cit., s. 15.

37 Ibidem, s. 44.

38 Odnosząc tę kwestię do polskich uwarunkowań ustrojowo-prawnych, możemy powiedzieć, że o ile w ramach działań mieszczących się w zasadzie subsydiarności horyzontalnej obywatele inicjują działania służące realizacji zasady dobra wspólnego, to w przypadku wolności zrzeszania się, na przykład w ramach uczestnictwa w stowarzyszeniach, realizowane mogą być cele, które nie są ani społecznie użyteczne, ani nawet realne.

39 Ibidem, s. 16. 
sektora pozarządowego). Wymaga to zatem, w wymiarze negatywnym, powstrzymania się przez władzę publiczną od realizacji zadań, które mogą być realizowane przez jednostki, grupy społeczne, wspólnoty, instytucje społeczeństwa obywatelskiego), natomiast w wymiarze pozytywnym — obowiązku udzielania pomocy ze strony władzy publicznej wymienionym podmiotom, oznaczającej zarówno pobudzanie, inspirowanie, podtrzymywanie, a także uzupełnianie ich wysiłków) ${ }^{40}$. Są to dwa integralne wymiary zasady pomocniczości poziomej. Doskonale ten stan wyraża Stanisław Konopacki: „idea pomocniczości jest zaprzeczeniem raz na zawsze ustalonego podziału kompetencji. Jest wyrazem poszukiwania, ciągle niestałej równowagi między potrzebą ingerencji z jednej strony i koniecznością nieingerencji z drugiej" ${ }^{41}$.

W nieprawniczej literaturze przedmiotu podnoszona jest kwestia rozróżnienia pomiędzy uczestnictwem i demokracją partycypacyjną a subsydiarnością horyzontalną. Alessandro Colombo w swojej rozbudowanej analizie poświęconej zasadzie subsydiarności (w jej wymiarach wertykalnym i horyzontalnym) zwraca uwagę na pewną znaczącą różnicę. Mianowicie, jak stwierdza, zasady uczestnictwa i demokracji partycypacyjnej nie wyrażają tak samo jednoznacznie (jak czyni to zasada subsydiarności horyzontalnej), że obywatele nie tylko muszą być konsultowani i włączani do spraw publicznych (poprzez różne instytucje) — ale przede wszystkim, że mają oni prawo podejmowania niezależnych inicjatyw, niekoniecznie oczekując na wykonanie pierwszego kroku przez instytucje publiczne ${ }^{42}$.

Nie podzielam stanowiska co do swoiście biernego statusu obywateli w demokracji partycypacyjnej. Bliższy jest mi pogląd Giovanniego Sartori na ten temat i prezentowana przez niego teoria uczestnictwa ${ }^{43}$. W głównym nurcie teorii demokracji nie tylko podkreśla się znaczenie uczestnictwa dla demokracji, ale przede wszystkim charakteryzuje się je jako „zaangażowanie osobiste i aktywne”44.

Zapewne granica podziału pomiędzy demokracją partycypacyjną a subsydiarnością horyzontalną oparta o kryterium ,intensywności uczestnictwa obywateli” jest zbyt nieostra, by się na niej oprzeć. Tym niemniej, dopełniając charakterystyki zasady subsydiarności horyzontalnej, warto jest podkreślić jej jednoznacznie aktywny charakter. To reprezentanci społeczeństwa obywatelskiego z własnej inicjatywy podejmują działania, których treścią jest realizacja zadań publicznych.

40 Por. Ch. Millon-Delsol, op. cit., s. 8-9.

41 S. Konopacki, Ponowoczesna subsydiarność, „Kultura Współczesna. Teorie. Interpretacje. Praktyka" 1997, nr 1, s. 95.

42 A. Colombo, op. cit., s. 43-44.

43 G. Sartori podkreśla, że właściwie i sensownie pojmowane uczestnictwo polega na „osobistym udziale, aktywnym i chętnym włączaniu się”. Nie jest więc ono prozaicznym „byciem częścią czegoś”, a tym bardziej nie chcianym, przymusowym „włączaniem do czegoś”. Uczestnictwo stwierdza Sartori - to ,ruch samoistny, dokładne przeciwieństwo bycia włączonym w ruch (z cudzej woli)..." - idem, Teoria demokracji, przeł. P. Amsterdamski, Warszawa 1998, s. 148.

44 Ibidem, s. 148-149. 


\section{Zakończenie}

Fundamentalne ustalenia Profesora Tadeusza Bigi dotyczące istoty związków publicznoprawnych wciąż inspirują do badań nad współczesnym znaczeniem korporacji terytorialnych, ich funkcjami i rolą jaką odgrywają we współczesnej demokracji.

Spojrzenie przez ich pryzmat na problematykę zasady pomocniczości doskonale obrazuje zależność, w jakiej pozostają zasada decentralizacji i zasada subsydiarności. Ich sprzęgnięcie wyraża określoną filozofię sprawowania władzy w państwie - władzy, której rolą nie jest wyręczać (zastępować) jednostki (społeczności) w zaspokajaniu ich potrzeb, lecz je wspierać i udzielać pomocy wówczas, gdy jednostki nie są w stanie zaspokoić potrzeb w warunkach działania indywidualnego (samodzielnego), jak i zbiorowego (wspólnotowego). Co więcej — taka władza musi być zdolna do dzielenia się zadaniami publicznymi z podmiotami prywatnymi (obywatelami, ich grupami, wspólnotami, tworzonymi przez nich organizacjami) i wspierającej ich inicjatywy. Przede wszystkim jednak, to władza uznająca publiczną rolę, jaką mogą i powinni odgrywać w życiu publicznym obywatele i tworzone przez nich instytucje. Jest to tym samym afirmacja władzy wyrastającej ze poziomu wspólnoty podstawowej.

Taki sposób pojmowania sprzęgnięcia ze sobą zasad decentralizacji i subsydiarności, wynikających z tego konsekwencji, roli, jaką w tym zakresie mają do odegrania struktury samorządowe, w mojej ocenie odpowiada refleksji Tadeusza Bigi (zawartej w motto niniejszego opracowania) co do roli samorządu terytorialnego jako ogniwa w procesie zespalania jednostki ze zbiorowością.

\section{$* * *$}

„Za każdym wybitnym człowiekiem stoi wybitny nauczyciel. Gdy każdy $\mathrm{z}$ nas zastanawia się nad tym czego dokona w życiu, najprawdopodobniej uda mu się to osiągnąć, jeśli tylko będzie miał dobrego nauczyciela"45. Tą myślą Stephen Hawking, jeden z najwybitniejszych w historii fizyków teoretycznych, podkreślał rolę postaci nauczyciela. Zdanie to nabiera szczególnego znaczenia współcześnie, gdy, jesteśmy świadkami globalnego buntu przeciwko autorytetom, w tym zwłaszcza autorytetom naukowym ${ }^{46}$ — dodawał. Niewątpliwie prof. Tadeusz Bigo, współtwórca wrocławskiej szkoły administracyjnej, jeden z luminarzy nauki polskiej, najpełniej odpowiada Hawkingowskiemu wyobrażeniu nauczy-

45 S. Hawking, Krótkie odpowiedzi na wielkie pytania, przeł. M. Krośniak, Poznań 2018, s. 232.

46 Ibidem. 
ciela. Pod tym zdaniem podpisać się mogą całe pokolenia badaczy ośrodka wrocławskiego. I nie tylko oni. Również ci naukowcy, którym nie było dane bezpośredniego zetknąć się z prof. Tadeuszem Bigą, mogą korzystać z jego naukowej spuścizny. Jest ona wciąż żywa, nieustająco inspirująca i pozwala na specyficzny ogląd „samorządowej współczesności” współczesnego modelu samorządu terytorialnego z perspektywy dokonanych przez niego kanonicznych ustaleń.

\section{Bibliografia}

Bigo T., Związki publiczno-prawne w świetle ustawodawstwa polskiego, Warszawa 1928.

Bigo T., Prawo administracyjne, cz. 1. Instytucje ogólne, oprac. W. Kawka, Wrocław 1948.

Cahill M., Theorizing Subsidiarity: Towards an ontology-sensitive approach, „International Journal of Constitutional Law" 15, 2017, nr 1.

Colombo A., The Principle of Subsidiarity and European Citizenship, Milan 2004.

Dolnicki B., Samorzad terytorialny, Warszawa 2012.

Donk W. van de, Subsidiarity as an experience and inspiration: The case for Regionomics in North Brabant, „European View” 18, 2019, nr 1.

Finnis J., Prawo naturalne i uprawnienia naturalne, przeł. K. Lossman, Warszawa 2001.

Hawking S., Krótkie odpowiedzi na wielkie pytania, przeł. M. Krośniak, Poznań 2018.

Izdebski H., Doktryny polityczno-prawne. Fundamenty współczesnych państw, Warszawa 2015.

Izdebski H., Samorząd terytorialny. Podstawy ustroju i działalności, Warszawa 2011.

Jan Paweł II, Encyklika Centesimus annus, [w:] Encykliki Ojca Świętego Jana Pawła II, t. 2, Kraków 1996.

Konopacki S., Ponowoczesna subsydiarność, „Kultura Współczesna. Teorie. Interpretacje. Praktyka" 1997, nr 1.

Korczak J., Konstytucyjne podstawy struktury i funkcji samorzadu terytorialnego, [w:] System Prawa Administracyjnego, t. 2. Konstytucyjne podstawy funkcjonowania administracji publicznej, red. R. Hauser, Z. Niewiadomski, A. Wróbel, Warszawa 2012.

Kruczkowski M., Zasada pomocniczości w prawie publicznym Włoch, „Zeszyty Prawnicze Biura Analiz Sejmowych" 2014, nr 1.

Leon XIII, Rerum Novarum z 15 maja 1891 roku, przeł., wstęp i objaśnienia J. Piwowarczyk, Kraków 1931.

Lipowicz I., Samorząd terytorialny XXI wieku, Warszawa 2019.

Millon-Delsol Ch., Zasada pomocniczości, Kraków 1995.

Mulé R., Walzenbach G., Introduction: two spaces of subsidiarity?, „Commonwealth \& Comparative Politics" 57, 2019, nr 2.

Panejko J., Geneza i podstawy samorządu europejskiego, Paryż 1926.

Pius XI, Quadragesimo Anno z 15 maja 1931 roku, przeł., wstęp i komentarz J. Piwowarczyk, Kielce 1946.

Platon, Państwo, przeł. W. Witwicki, Kęty 2003.

Sartori G., Teoria demokracji, przeł. P. Amsterdamski, D. Grinberg, Warszawa 1998.

Wacinkiewicz D., Zaspokajanie potrzeb wspólnot samorzqdowych. Studium administracyjnoprawne, Warszawa 2016.

Wacinkiewicz D., Horizontal dimension of subsidiarity in the activity of Polish local government, Granada 2020.

Prawo 333, 2021

(C) for this edition by CNS 


\title{
Horizontal Dimension of Subsidiarity: Comments in the Context of Tadeusz Bigo's Concept of Decentralization and Local Government
}

\begin{abstract}
Summary
A look at the subject matter of the subsidiarity principle through the prism of the research conducted by Professor Bigo on public law relationships as well as its results excellently expresses the coupling that occurs between the decentralisation and subsidiarity principles. These principles complement each other perfectly, pointing to a specific manner of exercising authority — based on the understanding of the public role citizens and institutions created by them may and should play in public life; authority which is able to share public tasks with private entities (citizens, their groupings or organizations established by them) and supports initiatives.

Now, apart from the vertical set-up, the horizontal dimension of the subsidiarity principle is attributed with increasing importance. Its essence is to ensure such a way of performing public tasks that they are implemented to the greatest degree possible by civil society measures. Public authorities, including local government units, act in such a model as intermediaries between the citizens and the state. This means that a certain "division of labour" between the public and civil sectors must be created.
\end{abstract}

Keywords: subsidiarity, horizontal subsidiarity, decentralization, local government. 